\title{
Consumer protection in the digital environment
}

\author{
Elena Agibalova ${ }^{1, *}$, Igor Ilovaysky ${ }^{2}$, Yanina Kayl $^{3}$, and Viktoria Usanova ${ }^{4}$ \\ ${ }^{1}$ Volgograd Institute of Management - Branch of the Russian Presidential Academy of National Economy and Public \\ Administration Volgograd, Russia, agibalovaen76@mail.ru \\ ${ }^{2}$ Volgograd Institute of Management - Branch of the Russian Presidential Academy of National Economy and Public \\ Administration Volgograd, Russia, dominno@rambler.ru \\ ${ }^{3}$ Volgograd Institute of Management - Branch of the Russian Presidential Academy of National Economy and Public \\ Administration Volgograd, Russia, yanika@bk.ru \\ ${ }^{4}$ Volgograd Institute of Management - Branch of the Russian Presidential Academy of National Economy and Public \\ Administration Volgograd, Russian Federation, vau_77@mail.ru
}

\begin{abstract}
The study examines the positive and negative aspects of the spread of digital technologies on legal relations with the participation of consumers. The relevance of the research is due to the complexity of the online environment, in which consumers are vulnerable to risks and challenges that affect their ability to participate in digital transformation. The categories of persons most vulnerable in the digital age are considered; factors contributing to this process; possible counteraction measures by the competent authorities. The purpose of studying these issues is to determine the basis of legal regulation of relations arising in connection with the digitalization of the economy, as well as to justify the improvement of domestic legislation in this area. The main research method was a systematic analysis of the categories "digital environment" and "consumer rights", as well as a general scientific dialectical method, specific scientific and empirical methods of cognition. The study confirmed the hypothesis that consumers of digital goods (services) are less protected than consumers of traditional goods (services), however, the authors conclude that it is necessary to equally protect the rights of consumers of all social groups, while establishing special protection measures for the most vulnerable of them.
\end{abstract}

\section{Introduction}

1.1 The digitalization process started with the most significant and extensive areas of society, including areas with weakness, such as consumer rights. Digitalization is having a profound impact on our society and economy, changing the way consumers interact with each other and with the online marketplace. In this context, consumer data became an important economic asset, enabling a wide range of innovative business models, technologies and transactions. With the increasing complexity of the online environment, consumers may be vulnerable to real or potential risks and challenges that could affect their ability to participate effectively in digital transformation.

1.2 The digital transformation of society and the economy brought many new business opportunities to consumers, but also contributed to a number of new risks. It also touched on long-standing consumer policy issues: inaccurate information about goods (works, services); misuse of consumer personal data; crossborder fraudulent and misleading commercial practices; unsafe products; international cooperation on consumer protection, including law enforcement; dispute resolution and redress procedures; sustainable consumption; protection of the most vulnerable categories of consumers.

1.3 The relevance of the topic is due to objective processes of consumer market development and common for many countries tendencies to improve the legal regulation of relations involving consumers.

Every year since 2017, Consumers International (CI) has defined consumer rights in the digital age with the theme of World Consumer Day on 15 March [1].

To protect the rights of consumers, the Government of the Russian Federation approved the Strategy of state policy in the field of consumer protection for the period till 2030 by Order No. 1837-r of 28 August 2017 [2]. Order No. 1197 of 29 December 2018 of the Federal Service for Supervision of Consumer Protection and Human Welfare (Rospotrebnadzor) approved the Concept of Consumer Protection Legislation [3] based on a preliminary analysis of experience in systematizing legal provisions in a number of states (Germany, Italy, Brazil). In 2020, Rospotrebnadzor [4] proposed sweeping amendments to the Russian Federation Law of

*Corresponding author: agibalovaen76@mail.ru 
7 February 1992 No 2300-I "On Consumer Protection" [5]. Although these documents do not specifically address the issue of consumer protection in the digital environment, they touch on it.

In Russia, special acts in this area have been discussed in draft form since 2000, but have not yet been adopted. For example, the draft Recommendations on the organization of individuals' activities in the sphere of Internet commerce, designed to harmonize the development of such activities in the Russian segment [6] and the draft Federal Law "On electronic commerce" [7] aimed at protecting the rights of interested parties in selling goods and services using information technologies.

The current version of the 2016 Recommendations on Consumer Protection in E-Commerce of the Organization for Economic Cooperation and Development (OECD) provides a solid basis for guiding global online marketplace policy [8]. However, governments around the world need to do more in consumer protection to keep up with the pace of change inherent in digital technologies and provide consumers with adapted protections and tools to enable them to participate effectively in the digital environment.

\section{Problem Statement}

2.1The study aims to substantiate the impact of the digital economy on consumer rights, to consider the positive and negative aspects of spreading digital technologies on legal relations involving consumers, to identify the current status and problems of consumer protection in a digital environment, as well as specific ways to protect consumer rights in the emerging environment, including through digital technology.

2.2 The authors intend to confirm the hypothesis that consumers of digital goods (services) are less protected than consumers of traditional goods (services), and to find out who the most vulnerable consumers are in the digital age, which categories of consumers may be particularly at risk and what can potentially be done to reduce consumer vulnerability in the digital transformation of society.

\section{Research Questions}

3.1 The research focuses on the impact of digital technologies on legal relations involving consumers and the current state of consumer protection in the digital economy.

3.2The authors pay special attention to the issue of impermissible conditions in contracts with consumers that infringe their rights, including the unauthorized collection of personal data about consumers, which has become particularly relevant in light of the extensive draft amendments to the Consumer Rights Protection Law prepared by Rospotrebnadzor in 2020 [4].

3.3 As the online environment may affect the ability of consumers to engage in digital transformation, the authors bring up the following issues for discussion:
1. Who is most vulnerable in the digital age (e.g. children, teenagers or the elderly)?

2. What factors can make consumers most vulnerable?

3. What can consumer protection authorities do to address consumer vulnerability in the digital age?

\section{Purpose of the Study}

4.1 The purpose of the study is to identify the basics of legal regulation of new social relations emerging due to the digitalization of certain social spheres, to substantiate ways to develop legislation on consumer protection in a digitalized economy, considering the balance of interests of society, the state, the online market, as well as consumers of its goods, works and services.

4.2 The introduction of a previously developed institutional model will protect the rights of consumers buying goods and services through information technology, which will improve the institutional protection of the rights of such parties through the creation of a mandatory e-commerce entrepreneurship insurance and e-commerce contract institute, as well as through the optimization of existing institutions by standardizing, strictly selecting and controlling ecommerce entrepreneurship (including intermediation) [9]. However, the authors aim to further develop specific ways to protect consumer rights by shifting the focus of this study to protect the most vulnerable consumer groups in the digital environment.

\section{Research Methods}

5.1 The research methodology relies on the general scientific dialectical method of knowledge and special scientific research methods: the formal-legal method, the method of interpretation of legal norms and the method of legal modelling. The authors used empirical methods of comparison, description and interpretation. The decisive method of research was a systematic analysis of the categories of "digital environment" and "consumer rights" in terms of their impact on the current state of civil regulation of social relations in the protection of violated civil rights.

5.2 The information and analytical basis for this study included: a) Rospotrebnadzor state reports containing objective systematized analytical information on the results of federal state supervision of consumer protection in the Russian Federation in 2018 and 2019 and serving as the basis for identifying priority areas for consumer protection, developing necessary measures to ensure consumer protection, and improving the legal and regulatory framework in the field $[3,10] ; b)$ the experience of foreign countries in the field.

\section{Findings}

\subsection{The impact of digital technology on legal relations involving consumers}


The study revealed that the positive aspects of the impact of digital technology on legal relations involving consumers include access to a wider range of goods and services; elimination of human error (minimization of risk) in the production, storage, sale, shipment (shipping) of goods; greater control over the production, storage, sale, shipment (shipping) of goods; elimination of the possibility of digital data tampering associated with the provision of goods and services.

The challenges of digitalization in this area may include: the lack of a realistic opportunity for consumers to inspect and test goods during an online sale; insufficient attention to consumer protection by sellers; inattention by consumers themselves when accepting the terms of a public offer, making it difficult to protect their rights later; an unauthorized collection of personal data about consumers, including by various smart devices; need to build consumer trust in online retailing; lack of legal regulation of online retailing relations in the near future.

The lack of consumer protection in the sale of goods and services using information technology is a serious problem for the development of e-commerce in modern Russia. This is a drawback of e-commerce compared to traditional trade, which reduces the attractiveness of this trade format [9].

\subsection{The current state of consumer protection in the digital economy}

At this stage of the digital economy, there is a lack of legal protection for consumer rights in electronic transactions. Our analysis of regulatory issues relating to the sale of goods and services using information technologies in Russia has shown that a likely deterrent to the development of electronic commerce is the lack of considering the specifics of this format in existing legislation and the pending draft of a Russian Federal Law "On electronic commerce" [7], designed to reduce uncertainty and guarantee the protection of stakeholders' rights when selling goods and services using information technology [9].

The lack of a specific regulatory framework generates many violations. Some sellers misunderstand that the Consumer Protection Act only applies to transactions made off the Internet. Resolution No. 17 of the Plenum of the Supreme Court of the Russian Federation of 28 June 2012 "On Consideration by the Courts of Civil Cases on Disputes concerning Protection of Consumer Rights" [11] also does not directly address issues of consumer protection in the digital environment. The authors believe that there is a way to remedy this situation by adding to the Act that its provisions apply equally to relations arising in the digital sphere.

At the same time, it is still possible to restore the consumer's violated rights through the Law, in particular Article 26.1 ("Distance selling of goods"), if the unfair seller is a resident of the Russian Federation. But transactions with a foreign seller have not been sufficiently regulated at present. International instruments such as the 1994 General Agreement on
Trade in Services (GATS) [12], the Model Law on Electronic Commerce developed and adopted by the United Nations Commission on Trade and Development [UNCITRAL] in 1996 [13], do not contain rules that govern the prosecution of offenders. This is why foreign online hypermarkets (e.g. AliExpress), as well as domestic ones, offer the use of buyer protection programmes developed by them. The relationship in digital trade is increasingly based on self-regulation by its participants. There is an opinion that the development of the digital economy will soon lead to autonomous consumer protection without state intervention [14].

Active changes in the economy, including those associated with the digitalization of sales channels, the transition to remote interaction with the consumer, the emergence of new objects of civil rights (digital products, smart electronics, the Internet of Things, personal data arrays, etc.) lead to an objective need to revise both basic and specific rules that ensure fundamental consumer rights.

\subsection{The problem of unauthorized collection of personal data on consumers and other unacceptable contract terms that infringe on their rights}

In 2020, Rospotrebnadzor drafted a bill to amend the Consumer Protection Act. The changes will affect Article 16 of the Act, which in the new version will be called "Unacceptable contract terms that infringe on the rights of consumers". The main message of the amendments, according to Rospotrebnadzor, is an attempt to protect citizens from the unlawful collection of personal data by retailers that is not directly related to the transaction. The seller will no longer be able to refuse a consumer into a contract if the consumer does not want to provide the relevant information. "Also to implement the principle of protecting the weaker party to the contract, the draft law provides a list of conditions that infringe on consumers' rights," reads an explanatory note to the draft [4]. It is about conditions included in contracts that the Rospotrebnadzor and, according to its reports, the courts consider to be contrary to the law. As a result, the Law will contain dozens of bans and restrictions on business and, according to some authors, will effectively nullify all attempts by entrepreneurs to prevent consumer extremism and other forms of abuse of rights [15].

Analysing draft Article 16 of the Consumer Rights Protection Law, the authors concluded that Russia is now proposing to introduce, following the European model, a blacklist of unacceptable conditions in a contract with a consumer. However, the European blacklists are much longer and better elaborated. We think that Rospotrebnadzor should have worked with them. In the European Union (hereinafter EU), consumer protection has advanced by dozens of years compared to Russian law. For example, there is the Council of the European Communities Directive on unfair terms in contracts with consumers [16] and the experience of its implementation in all EU countries, as well as numerous 
publications on the issue. In our view, this was totally overlooked by the drafter of the Consumer Protection Act amendments.

Most importantly, it is very strange that there is no proposal to establish a general rule on the nullity of unfair terms in a consumer contract, giving the court jurisdiction to assess any consumer contract terms for the balance of interests of the parties for protecting the weaker party. This right is available to judges in all European countries and even in England, where ex post control of contractual fairness is generally not developed. The Constitutional Court of the Russian Federation demands the same.

The courts in the Russian Federation are now forced to exercise ex post control over the fairness of consumer contracts under a creative reading of Article 16.1 of the Consumer Protection Law, which literally says exactly the opposite - that conditions that contradict imperative consumer law norms are null and void in terms of worsening the consumer's legal position. In effect, this clause declares all such default rules to be asymmetricimperative. It is possible to improve the position of the consumer in comparison to such rules, but not to worsen them. However, the problem is that it is hard to write imperative rules for all occasions, and the imagination of traders is limitless. So, our courts do what they can. Europe everywhere has long imposed ex post controls on the fairness of consumer contracts. But in Russia, the courts, including the Supreme Court of the Russian Federation, are forced each time to fictitiously apply the literally unrelated paragraph 1 of Article 16 of the Consumer Rights Protection Law in such a situation to protect the consumer from the unfair conditions imposed on him. For example, in terms of setting fees, claims procedures, etc., there is a need to call things by their proper names and recognise that courts can overturn manifestly unfair terms in consumer contracts rather than pretending that such terms are allegedly contrary to some norm, for there are none. Especially since the doctrine of unfair terms has long developed in our country, with the Resolution of the Plenum of the Supreme Arbitration Court of the Russian Federation on freedom of contract and its limits [17] and Article 428 of the Russian Civil Code [18] in force. The authors of this study suggest that Rospotrebnadzor should take these circumstances into account when drafting the final version of Article 16 of the Consumer Rights Protection Law. It is necessary to enshrine a general rule on the nullity of unfair terms of a consumer contract, giving the court the competence to assess any terms of a consumer contract for the balance of interests of the parties in the new version of Article 16 of the Consumer Protection Law to protect the weaker party.

\subsection{The problem of consumers' greatest vulnerability in the digital environment}

As the OECD notes, most vulnerable consumers are consumers who are susceptible to harm at a given time because of the market characteristics of a particular product, the quality of the product, the nature of the transaction or the circumstances in which the consumer finds himself [19].

The United Nations Conference on Trade and Development (UNCTAD) highlighted that personal vulnerabilities include characteristics that expose the consumer to a significant risk of harm [20]. For example, a consumer may be most vulnerable because of their age, race, ethnicity or gender; low level of education or literacy; limited language skills; mental health problems; physical disabilities; geographical distance/residence in a low-density region; unemployment or low income [21]. Personal characteristics such as gullibility, impulsivity, risk aversion, poor calculation skills can also make consumers insecure [22]. Vulnerability can also result from personal circumstances such as bereavement, divorce or a period of illness [23].

Certain market characteristics such as lack of competition, insufficient information and/or market complexity can make consumers more vulnerable in particular markets [23-24]. In very complex markets, such as the financial services markets, even the most sophisticated consumer can feel insecure [23]. In such markets, consumers are often guided by simple rules of thumb or heuristic thinking, ignore certain opportunities or choose not to make consumer choices [21].

Certain qualities of the product may also cause the greatest vulnerability to consumers. For example, these could be complex products incorporating the Internet of Things and artificial intelligence technologies [25]. A lack of experience with online services that collect and use consumer data, combined with a lack of userfriendly privacy controls, leave many consumers vulnerable to privacy risks on the information and telecommunications network of the Internet.

Finally, consumers may be vulnerable because of the nature of the transaction. This could be, for example, a transaction involving mobile payments and in-game transactions, which are often made on-the-go, via small screens and may involve limited authentication controls [26-27]. There have been cases of unauthorized purchases made through voice-activated digital assistants $[25,28]$.

The Russian legal reality is currently actively introducing smart contracts (self-executing contract, selfexecuting transaction) that use blockchain technology [29]. There is the use of smart contracts in settlement relations, such as the settlement of letters of credit [30]. The use of computer technology in contracting and contract enforcement, in particular smart contracts, can also contribute to consumer vulnerability, as it implies knowledge of scientific and practical provisions related to both the law and technical sciences at the same time.

A number of factors indicate that it is in the digital environment that consumers are most vulnerable. All consumers have no protection from unfair commercial practices in the digital age, as sellers can take advantage of the limitations of a particular medium and transmit misleading advertising or pre-contractual information. The online environment provides new ways in which businesses can prey on behavioural biases, such as the framing effect, loss aversion and overconfidence. When shopping online, consumers suffer the detriment of 
misleading reference prices, bundled pricing, timelimited offers, scarcity signals and default settings. Since online businesses can collect consumer data and personalize offers and prices, it could be argued that all consumers are potentially vulnerable to digital marketplace manipulation.

However, we believe that the most vulnerable categories of consumers in a digitalized environment are children and teenagers, and the elderly, due to a lack/absence of critical judgement, literacy or relevant skills. We also include consumers with limited access to information and communication technologies (ICT) and little experience with the digital environment as a socially vulnerable group.

1. Children and teenagers. Despite their early experience of the Internet, children and teenagers are vulnerable in the digital environment because they lack the critical judgement necessary to determine the circumstances where they may be exposed to harm. This lack of critical judgement leaves them vulnerable to harm, especially when the commercial nature of the content is not disclosed or masked, as in advertising games, subscription traps, negative publicity, etc. [3132]. They are unable to resist targeted behavioural advertising when using apps and online games. However, Facebook, Instagram and Snapchat report advertising audience growth in 2020 among users aged 13 to 17 [33].

In addition, many children and young people lack the literacy and/or skills to understand the meaning of the information they encounter online, especially relating to privacy and the use of personal data. We believe that the practice of forcing children and teenagers to consent to the use of their data for marketing purposes to access online services should be prohibited. Children and teenagers cannot give informed consent because they are not required to read and understand the very complex terms/confidentiality notices.

The widespread use of smartphones, digital assistants and other mobile devices by children and teenagers poses additional challenges. Parents or guardians find it more difficult to supervise children and teenagers who manipulate with these devices. For example, when there are no adequate authentication and payment controls, children and teenagers may make purchases without the consent of their legal representatives [27]. Lack of supervision for minors and underage people can lead them to view inappropriate commercial content, such as advertisements for prohibited items [35].

2. Older consumers. Compared to children and teenagers, older consumers tend to have less experience with the Internet and have lower ICT skills. As a result, they are more likely to face security risks. In the UK, for example, consumers aged 65 and over often fail to check the reliability of an online website before posting their credit card details [23].

Older people are more susceptible to misleading marketing practices and often fall victim to online dating scams, romance scams, lotteries, inheritance, investments [23]. After all, they tend to be lonely, more trusting and more likely to suffer from vulnerabilities such as health conditions, physical disabilities, mental illness or cognitive impairment, making them vulnerable to scammers [23].

Research shows that older people are most vulnerable in mainstream markets (such as energy, water, telecommunications, financial services) and markets for special services for older people (e.g. care homes, funeral homes, pension funds) [23]. While these markets are not new to the digital age, digital innovation has transformed many of them so that older consumers can only get their benefits online. In addition, given that some older consumers have limited ability to use online services, business policies that provide access to and/or discounts on basic services only to online consumers are infringing on the rights of older people.

According to the Federal State Statistics Service (Rosstat), the elderly are twice as likely as young people to use a computer. Half of the older generation uses the Internet, and only a third of them are active users. They communicate on social media (57\%), search for information related to health topics $(49 \%)$, use messengers to make calls and video calls $(46 \%)$ and analyse data about products and services (45\%). Only $10 \%$ of older consumers use the internet to order goods or services online. Their most popular services include financial transactions, including banking services, money transfers, insurance services, securities transactions $(46 \%)$, clothes and shoes $(36 \%)$, and household goods (26\%). $73 \%$ of older people surveyed pay for their purchases using bank cards. Only just over a quarter of people over 55 actively use online access to public services. The most demanded services are those related to health care and medicine $(35 \%)$, payment of taxes and fees (17\%), and housing and utilities obligations (14\%) [36].

3. Consumers with limited access to ICTs. To participate effectively in e-commerce, consumers need access to quality communication infrastructures as well as the appropriate skills to navigate the online environment. Lack of access to ICT and experience with the digital environment affects consumer vulnerability.

At the beginning of 2020 , more than 4.5 billion people are using the Internet. Almost $60 \%$ of the world's population is already online. In Russia, the number of internet users in 2020 is 118 million. This means that $81 \%$ of Russians use the Internet. However, barriers remain that prevent people all over the world from having fair and equal access to the digital environment. Today, more than $40 \%$ of the world's population, some 3.2 billion people, are not yet connected to the Internet. More than a billion "unconnected" people live in South Asia $(31 \%$ of the total). African countries account for $27 \%$. There is a correlation between Internet access and the age of users in these regions: more than half of Africa's under-20s and more than 460 million people under 13 in South Asia are not online.

There is an inequality between the number of men and women on the Internet. Women are less likely to be online than men. The gap is particularly wide in developing countries. For example, women in South Asia today are three times less likely to use social media than men. More than half of the women now living in India are not aware of the existence of mobile Internet at 
all. This inequality results from a range of factors, including access, cost, lack of education, skills and technological literacy, as well as innate gender biases and socio-cultural norms. The main reason for this imbalance lies in deeply rooted social norms and traditions. Regardless of the cause, the number of "unconnected" people will depend to a large extent on increasing digital accessibility for women, especially in developing countries [33].

There is a gap in Internet access between rural and urban areas, with rural areas tending to lag urban areas in being able to use the Internet at high speeds.

Thus, lack of access and/or ICT skills leads to a digital divide, which is significant for people in rural areas, older people, women, people in developing countries, less educated people, and people with disabilities and the poor [23]. As businesses do not always develop digital goods and services tailored to the specific needs of the listed minority groups, it is necessary to classify them among the most vulnerable categories of consumers in the digital environment.

\subsection{Ways to address consumer protection in the digital age}

Analysing the possible ways of protecting consumer rights in the digital environment, the authors conclude that it is necessary to equally protect the rights of consumers of all social groups, including through digital technologies, while establishing special protections for socially vulnerable groups.

The Russian Federation has now developed an effective mechanism for consumer protection authorities to apply enforcement measures. As of 1 October 2019, a new form of judicial protection for consumer rights has become class action lawsuits [37]. Rospotrebnadzor is developing online dispute resolution mechanisms - new effective forms of consumer protection.

However, we believe that targeted policies to encourage consumer-oriented business practices, investment in ICT access, and education and awareness campaigns can help protect and empower consumers in the digital age.

1. The incentive policy way. Some foreign countries developed and successfully implemented specific policies targeting vulnerable consumers to protect them in the online environment. The Children's Online Privacy Protection Act of October 21, 1998 [COPPA] [38] prohibits the collection, use and disclosure of personal information about children on the Internet without parental consent. The law applies to operators of commercial websites and online services (including online advertising) aimed at children under the age of 13 . The UK encourages entrepreneurial policies focused on markets for older people and other innovations for socially vulnerable consumers [23].

Improved business processes, better business practices by entrepreneurs will contribute to consumer protection when problems arise in a particular market or for a particular group of vulnerable consumers. In recent years, abroad there were several initiatives to self- regulate internet marketing aimed at children and other disadvantaged consumers [31]. Entrepreneurs themselves have proposed effective tools to help vulnerable consumers. In the UK, for example, some banks have allowed consumers to block dubious transactions [23]. There are free online tools that consumers can use to manage their online spending. Tools have been introduced to prevent children from making unauthorized purchases and viewing prohibited content online, which provide authorization and/or age verification of the user [26].

We believe that the state should encourage entrepreneurs who consider the challenges faced by the most vulnerable categories of consumers in the digital environment. And entrepreneurs should take the lead in making online goods (services) available to as many consumers as possible [23]. Market monitoring and law enforcement need to be improved to identify and combat unfair commercial practices related to consumer vulnerability in the digital environment.

2. Increasing access to ICTs and developing digital competencies. We believe the first harbinger of digital consumer empowerment is adequate ICT skills and literacy as well as accessibility to ICTs. There is worldwide recognition of the need for ICT literacy. Most countries teach children and young people ICT literacy in schools. While building digital competences is largely the responsibility of education authorities, we believe that consumer protection agencies can also play a role in developing targeted education and ICT literacy programmes.

Russia is currently implementing a programme of new digital professions from the government as part of the federal programme "Human Resources for the Digital Economy". Free training is available in over 20 areas that are in demand in the digital economy. In 2020, residents from 48 regions of the country participated in the programme and received 33,000 personal digital certificates [39].

3. Targeted information and awareness-raising campaigns. In some foreign countries, consumer protection agencies have developed and implemented information and awareness-raising campaigns for older consumers. For example, the Federal Trade Commission https://ru.wikipedia.org/wiki/\%D0\%90\%D0\%BD $\%$ D0\% B3\%D0\%BB\%D0\%B8\%D0\%B9\%D1\%81\%D0\%BA\% D0\%B8\%D0\%B9 \%D1\%8F\%D0\%B7\%D1\%8B\%D0\% $\mathrm{BA}(\mathrm{FTC})$ is implementing projects to protect older people from online fraud [40]. It also has a number of educational resources for children and young people on the Internet. Similarly, the European Commission developed a Children's Internet portal with numerous resources for children and teenagers in the digital age (EC, n.d.).

When running information and awareness-raising campaigns, the state should consider the importance of making them available in formats that meet the needs of vulnerable consumers. For example, in 2018, the Canadian Competition Bureau published the second edition of its educational guide on how to avoid cheating in the eight different languages spoken by new Canadians [41]. 
Russia also runs information and awareness-raising campaigns. For example, the Rospotrebnadzor website contains more than 75,000 materials, including 25,000 about products that do not comply with mandatory requirements, 360 information leaflets and guides, such as a leaflet to prevent deception of older people purchasing goods and services[42].

\section{Conclusion}

7.1 The study proves the hypothesis that consumers of digital goods (services) are less protected than consumers of traditional goods (services) and shows that, at this stage of the digital economy, consumer rights in digital transactions are not sufficiently protected, primarily at the legislative level. A huge number of irregularities result from the lack of a specific regulatory framework governing e-commerce. In this context, there is an emerging trend towards autonomous consumer protection on the basis of self-regulation by e-commerce players without state intervention.

7.2 It was revealed that although Rospotrebnadzor takes an active part in the discussion of international recommendations and approaches at the WTO, OECD, UNCTAD, etc., the work on improving domestic legislation in consumer protection field does not always consider the best international practices. The Rospotrebnadzor's 2020 draft amendments to the Consumer Rights Protection Law need improvement, as they do not consider the EU experience in regulating unacceptable terms of the contract with the consumer that infringe on their rights. By analogy with the practice in European countries, we propose that the new version of Article 16 of the Consumer Rights Protection Law should contain a general rule on the nullity of unfair consumer contract terms, giving the court jurisdiction to assess any consumer contract terms for the balance of interests of the parties to protect the weaker party.

7.3 We substantiate that all consumers are potentially vulnerable in the digital economy. A number of factors point to the greater vulnerability of consumers in the digital environment, as it implies not only legal literacy but also certain technical skills: the emergence of nontraditional digital sales channels and remote interaction, new objects of civil rights (digital products, smart electronics, Internet of Things, personal data sets, etc.), the use of smart contracts and blockchain technology in contract negotiation and enforcement. However, the most digitally disadvantaged categories of consumers are children and teenagers, the elderly, consumers with limited access to ICTs and lack of experience with them.

Toward addressing consumer protection in the digital economy, the authors propose to ensure equal consumer protection for all social groups, including through digital technologies, while establishing special protections for socially vulnerable groups through public policies to encourage entrepreneurship, increase access to ICT and develop digital competencies, as well as targeted information and awareness-raising campaigns. The main objective of consumer protection in the digital environment is to reduce consumer risks.

\section{References}

1. World consumer rights day 2017 calls for protecting consumer rights in the digital age (2017), URL: https://zppdon.ru/news/9234/ (date of access: 16.03.21).

2. Government of the Russian Federation. The decree of the Government of the Russian Federation "On approval of Strategy of state policy of the Russian Federation in the field of consumer protection for the period till 2030" (August 28, 2017 No. 1837-r). Moscow, Russia (2017)

3. Federal service for supervision of consumer protection and human welfare [Rospotrebnadzor]. Consumer protection in the Russian Federation in 2018: State report. Moscow, Russia (2019a)

4. Federal service for supervision of consumer rights protection and human welfare [Rospotrebnadzor] (2020a), URL: http://www.consultant.ru/cons/cgi/online.cgi?re $\mathrm{q}=$ doc\&base $=$ PRJ\&n=199634\#0719158699309 6075 (date of access: 16.03.21).

5. Russian Federation. Law of the Russian Federation "On consumer protection" (February 7, 1992 No. 2300-1). Moscow, Russia (1992)

6. V. Naumov, Recommendations for organizing the activities of individuals in the field of Internet Commerce in the Russian Federation (2000),

URL:

https://www.osp.ru/ecom/2000/07/13031267 (date of access: 16.03.21).

7. Draft Federal law No. 310163-4 "On electronic Commerce" (2006), URL: www.consultant.ru/cons/cgi/online.cgi?req $=\mathrm{doc}$ \&base=PRJ\&n=42158\#028127057741049954 (date of access: 16.03.21).

8. Organization for Economic Cooperation and Development [OECD]. (2016), URL: https://dx.doi.org/10.1787/9789264255258-en

9. I.B Ilovaysky, Y.Y Kayl, D.A. Tokarev \& V.A. Usanova Institutional Model for the Protection of Rights of the Parties Concerned in the Sale of Goods and Services with the Use of Information Technologies. (Switzerland, Cham: Springer Science + Business Media, 2019)

10. Federal service for supervision of consumer protection and human welfare [Rospotrebnadzor]. Consumer protection in the Russian Federation in 2019: State report. Moscow, Russia (2020b)

11. Plenum of the Supreme Court of the Russian Federation. The resolution of Plenum of the Supreme Court of the Russian Federation "About consideration by courts of civil cases on disputes on protection of consumer rights" (June 28, 2012 No. 17). Moscow, Russia (2012)

12. World trade organization [WTO] (1994), URL: http://ivo.garant.ru/\#/document/2541542/paragr aph/650:0 (date of access: 16.03.21). 
13. United Nations Commission on international trade law [UNCITRAL]. (1996), URL: https://base.garant.ru/2555780/ (date of access: 16.03.21).

14. Y.A. Vasilyeva, Risks for consumers of logistics services in the conditions of digitalization of society (Saint Petersburg, Russia: Kult-informpress publishing house, 2019)

15. E. Krivtsov The law "On consumer protection" is being changed to suit judicial practice and the views of officials. Legal. Repert. (2020), URL: ://legal.report/zakon-o-zashhite-pravpotrebitelej-izmenyajut-pod-sudebnujupraktiku-i-vzglyady-chinovnikov/ (date of access: 16.03.21).

16. Council of the European Communities [EEC] (April 5, 1993 No. 93/13/EEC) (1993), URL: https://base.garant.ru/2565749/ (date of access: 16.03.21).

17. Plenum of the Supreme Arbitration Court of the Russian Federation. (2014). Resolution of the Plenum of the Supreme Arbitration Court of the Russian Federation "Freedom of contract and its limits" (March 14, 2014 No. 16, Moscow, Russia)

18. Russian Federation. (1994). Civil code of the Russian Federation (part one) (November 30, 1994 No. 51-FZ, Moscow, Russia)

19. Organization for Economic Cooperation and Development [OECD]. (2014a), URL: http://www.oecd.org/sti/consumer/Toolkitrecommendation-booklet.pdf (date of access: 16.03.21).

20. United Nations Conference on Trade and Development [UNCTAD]. (2018), URL: https://unctad.org/meetings/en/Presentation/WG $\% 20$ Vulnerable $\% 20$ and $\% 20$ Disadvantaged $\% 20$ Consumers\%20.pdf (date of access: 16.03.21).

21. Organization for Economic Cooperation and Development [OECD]. (2010), URL: https://dx.doi.org/10.1787/9789264079663-en (date of access: 16.03.21).

22. European Commission [EC] (2016), URL: https://ec.europa.eu/info/sites/info/files/consum er-vulnerabilityfactsheet en.pdf (date of access: 16.03.21)

23. Competition and Markets Authority UK [UK CMA]. Consumer vulnerability: challenges and potential solutions. (2019), URL: https://www.gov.uk/government/publications/c onsumer-vulnerability-challenges-andpotentialsolutions/consumer-vulnerability-challengesand-potential-solutions(date of access: 16.03.21).

24. Consumer Affairs Victoria [CAV]. What do we mean by vulnerable and disadvantaged consumers? (2004), URL: https://www.consumer.vic.gov.au/library/public ations/resources-andeducation/research/whatdo-we-mean-by-vulnerable-and-disadvantagedconsumersdiscussion-paper-2004.pdf (date of access: 16.03.21).
25. United Nations Conference on Trade and Development [UNCTAD]. Working Group on Vulnerable and Disadvantaged Consumers Contribution, Intergovernmental Group of Experts on Consumer Law and Policy. (2018), URL:

https://unctad.org/meetings/en/Presentation/WG $\% 20$ Vulnerable $\% 20$ and $\% 20$ Disadvantaged $\% 20$ Consumers\%20.pdf (date of access: 16.03.21).

26. Organization for Economic Cooperation and Development [OECD]. Report on Consumer Protection in Online and Mobile Payments. Paris, France: OECD Publishing. (2012), URL: https://doi.org/10.1787/20716826(date of access: 16.03.21).

27. Organization for Economic Cooperation and Development [OECD]. Consumer Policy Guidance on Mobile and Online Payments. OECD (2014b), URL: https://dx.doi.org/10.1787/5jz432cl1ns7-en(date of access: 16.03.21).

28. Organization for Economic Cooperation and Development [OECD] (2019a), URL: https://one.oecd.org/document/DSTI/CP(2019)1 0/FINAL/en/pdf/(date of access: 16.03.21).

29. E.N. Agibalova, Scientific and Technical Revolution: Yesterday, Today and Tomorrow. ISC 2019. Lecture Notes in Networks and Systems (Switzerland, Cham: Springer, 2020).

30. E.N. Agibalova, I.B. Ilovaysky, Y.Y Kayl \& V.A. Usanova, Scientific and Technical Revolution: Yesterday, Today and Tomorrow. ISC 2019. Lecture Notes in Networks and Systems (Switzerland, Cham: Springer, 2020)

31. Organization for Economic Cooperation and Development [OECD]. Good practice guide on online advertising. (2019b), URL: https://doi.org/10.1787/20716826 (date of access: 16.03.21).

32. United Nations Children's Fund [UNICEF]. Children and Digital Marketing: Rights, risks and responsibilities. (2018), URL: https://www.unicef.org/csr/css/Children_and_D igital Marketing -

Rights Risks and Responsibilities.pdf (date of access: 16.03.21).

33. Sergeeva Y. All Internet statistics for 2020 figures and trends in the world and Russia. (2020), URL: https://www.webcanape.ru/business/internet-2020-globalnayastatistika-i-trendy/ (date of access: 16.03.21).

34. Organization for Economic Cooperation and Development [OECD]. Consumer Policy Guidance on Mobile and Online Payments. OECD Digital Economy Papers, 236. (2014b), URL: https://dx.doi.org/10.1787/5jz432cl1ns7en (date of access: 16.03.21).

35. UK Council for Child Internet Safety [UKCCIS]. Children's online activities, risks and safety: A literature review by the UKCCIS Evidence Group. (2017), URL: https://assets.publishing.service.gov.uk/govern 
ment/uploads/system/uploads/attachment_data/f ile/650933/Literature_Review_Final_October_2 017.pdf (date of access: 16.03.21).

36. Federal state statistics service [Rosstat]. Results of a sample Federal statistical survey on the use of information technologies and information and telecommunications networks by the population. (2019), URL: https://rosstat.gov.ru/folder/313/document/6364 0 (date of access: 16.03.21).

37. Russian Federation. Federal law of "On amendments to certain legislative acts of the Russian Federation" (July 18, 2019 No. 191-FZ, Moscow, Russia)

38. The Children's Online Privacy Protection Act of October 21, 1998 [COPPA]. URL: https://www.govinfo.gov/content/pkg/PLAW105publ277/pdf/PLAW-105publ277.pdf (date of access: 16.03.21).

39. New digital profession from the state (n.d.). URL:

https://цифровойсертификат.pф/?utm_source=f b_wp\&utm_medium $=$ cpc\&utm campaign $=$ teach er\&utm term $=$ stat\&fbclid $=$ IwAR065dBxOY IP fwEm9Cd7s0jPN4Um i0imcdb1O1Ey9BNUBszibGMp44BY (date of access: 16.03.21).

40. Federal Trade Commission US [US FTC]. Protecting older consumers 2017-18: A report of the Federal Trade Commission. (2018), URL: https://www.ftc.gov/system/files/documents/repo rts/protecting-olderconsumers-2017-2018-reportcongress-federaltradecommission/protecting_older_consumers ftc report 10-18-18.pdf (date of access: 16.03.21).

41. Competition Bureau Canada. The Little Black Book of Scams 2nd edition. (2018), URL: https://www.competitionbureau.gc.ca/eic/site/cbbc.nsf/eng/04333.html (date of access: 16.03.21).

42. Federal service for supervision of consumer rights protection and human welfare [Rospotrebnadzor]. Recommendations to citizens: how to avoid becoming a victim of fraud? (2019b), URL: https://www.rospotrebnadzor.ru/about/info/news Inews details.php?ELEMENT ID=10961\&sphr ase $\mathrm{id}=1821993$ (date of access: 16.03.21). 